Original Contribution

\title{
THE FAMILY AS A FACTOR TO OVERCOME AGGRESSION IN ADOLESCENCE
}

\author{
B. Tilov*, B. Tornyova
}

Department of Health Care Management, Faculty of Public Health, Medical University, Plovdiv, Bulgaria

\begin{abstract}
PURPOSE: The purpose of the study is to examine to what extent the family environment influence the reduction of aggression in adolescence through a self-assessment question.

METHODS: The study group consists of 604 students, enrolled in eight secondary schools and vocational schools in the Town of Plovdiv. The age of students, participating in the study, is between 14 and 18 years. The analysis of the results shows that the distribution of boys is $54.14 \pm 2.03$ at $45.86 \pm$ 2.03 for girls.

RESULTS: The relation between this statement and the scales for measurement of the levels of aggressiveness is in all scales. For scale "physical aggression" $\mathrm{P}<0.001(\mathrm{~F}=8.99)$, "verbal aggression" $\mathrm{P}$ $<0.001(\mathrm{~F}=13.53)$, "anger" $\mathrm{P}<0.001(\mathrm{~F}=9.82)$, "hostility $\mathrm{P}<0.05(\mathrm{~F}=13.19)$ and "general aggression" $\mathrm{P}<0.001(\mathrm{~F}=10.49)$.

CONCLUSIONS: The family environment is the place, where the young person passes through the rapidly changing stages of his conscious life, stages associated with his physical, mental and emotional development. Undoubtedly, the authority of the parent or the guardian is the most significant determinant of the behavior of the adolescent.
\end{abstract}

Key words: aggression, adolescence, family, physical aggression, verbal aggression, anger, hostility

\section{INTRODUCTION}

Aggression and violence among children and adolescents are the subject of particular attention in recent years. Aggression is an increasingly common pattern in our reality among adolescents not only in school, but also outside it. We are observing a constant deformation of human relationships, both individually and in an overall socio-cultural plan. The patterns of behavior are increasingly changing in favor of violence, starting from an invisible base, an impulse which aims to achieve the desired objective.

Numerous authors, who are observing and studying aggression among adolescents, focus on the family environment and its paramount importance for the development of adolescent behavior. This raises the question to what extent aggressive behavior is due to the family and whether there is a clear link between aggressiveness in parents and in children. The multispectral researches show that family environment is a major factor in the onset and development of aggressive behavior (1- 6).

\footnotetext{
*Correspondence to: Boris Tilov, Medical University - Plovdiv, bul"Vasil Aprilov"15a Phone: +359887870401,e-mail: btilov@abv.bg
}

The influence on the development of aggressive behavior in adolescents occurs in specific behavioral models exhibited by parents. The adolescent, who at a very early age witnesses aggressive actions by both parents, creates and incorporates an automated response to his relations with the external environment. Young people, who have witnessed personality clashes and angry attacks, have proven to be more aggressive (7). The conflict relationships between parents, which have been closely witnessed by the adolescent, often become the model for behavior in similar situations. In the families of aggressive children the emotional connection between their members is destroyed in many of the cases. The relations are hostile and cold and alienation between parents and children and between the parents themselves can be observed. The fathers demonstrate pattern of aggressive behavior and encourage the aggressive behavior of their children. The mothers are demanding, but indifferent to their success. In these families the demands are contradictory and the adolescents form an oppositional behavior with pretensions to the people surrounding them. Parents of aggressive children in a large percentage of cases resorted 
to physical punishment, threats, deprivation of privileges, restrictions and lack of incentives, frequent isolation and conscious deprivation of love and care. The parents themselves almost never feel guilty, when punishing their children. They do not try to understand the reasons for their destructive behavior and are indifferent to their emotional life. When adolescents are left alone, objective conditions for aggression in their behavior can be created (8).

The aggressive behavior of adolescents is an expression of anger and protest. It is a signal for help and for attention to their inner world, in which too many destructive emotions have accumulated, with which the adolescents cannot cope on their own.

Empirical researches in this area establish a connection between the antisocial and the personality disorders of the parents and the development of similar behavior in children (912).

\section{MATERIAL AND METHODS}

The study group consists of 604 students, enrolled in eight secondary schools and vocational schools in the Town of Plovdiv. The age of students, participating in the study, is between 14 and 18 years. Of 641 participants, 37 people were excluded of the study due to incorrect or incomplete filling of questionnaires. We can summarize that the processed data of the persons involved in the study is $2.3 \%$ of the students in the city, making the sample representative for this study.

In the selection of the monitored schools representative partial monitoring was used. The collection of primary data was performed by the school psychologists, performing the function of organs of observation.

The study was conducted in the period between March 2010 and July 2010.
$41(6.8 \%)$ of the surveyed students are aged $14,119(19.7 \%)$ are the 15 year olds. The largest is the number of 17 year olds - 185 $(30.6 \%)$ and of the 16-year-old students -174 (28.8\%), 18 year olds are 85 of the respondents (14.1\%).

The analysis of the results shows that the distribution of boys is $54.14 \pm 2.03$ at $45.86 \pm$ 2.03 for girls. The larger proportion of boys to girls is indicative of a statistically significant difference, via the calculated U-criterion for normality of distribution, in which $\mathrm{P}<0.001$ $/ \mathrm{U}=3.39 /$.

\section{PURPOSE}

The purpose of the study is to examine to what extent the family environment influence the reduction of aggression in adolescence through a self-assessment question.

\section{RESULTS AND DISCUSSION}

The respondents were asked the following question regarding their subjective attitude on the issue of aggression: "Do you follow the rules in the family?". This question gives us basic information about the self-assessment of adolescents on the issue in hand. The answers to the question were studied according to three basic factorial attributes - age, gender and school.

Every third student indicated that he always respect the existing rules. Largest percentage of respondents indicated that they "sometimes" obey the rules, and only $5.30 \pm 0.89 \%$ replied that they "never" obey them.

\section{Distribution by gender}

From the results we can definitely conclude that gender strongly influences these responses from the respondents $-\mathrm{P}<0.01\left(\chi^{2}=12.30\right)$.

The calculated t-criterion confirms the larger relative share of responses of boys, who state that they "always" and "never" follow the rules in the family. For the girls, the larger percentage of respondents is associated with compliance with rules "sometimes" and "rarely".

Table 1. Response for follow the rules in the family

\begin{tabular}{lllllllllll}
\hline $\begin{array}{l}\text { Compliance } \\
\text { with rules }\end{array}$ & Girls & \multicolumn{1}{c}{ Boys } & \multicolumn{1}{c}{ Total } \\
\hline & Number & \% & Sp & Number & \% & Sp & Number & \% & t & P \\
Always & 87 & 41,4 & 3,40 & 123 & 58,6 & 3,40 & 210 & 100.0 & 3.58 & $<0.001$ \\
& & & & & & & & & & \\
Sometimes & 140 & 51,3 & 3.03 & 133 & 48,7 & 3.03 & 273 & 100.0 & 0.60 & $>0.05$ \\
Rarely & 41 & 46,1 & 5.28 & 48 & 53,9 & 5.28 & 89 & 100.0 & 1.05 & $>0.05$ \\
Never & 7 & 21,9 & 7.32 & 25 & 78,1 & 7.32 & 32 & 100.0 & 4.76 & $<0.001$ \\
All & 275 & 45,5 & 2.03 & 329 & 54,5 & 2.03 & 604 & 100.0 & 3.11 & $<0.01$ \\
\hline
\end{tabular}


From the data that clearly show the differences of the responses by gender can be established that boys are more likely to follow the rules in the family than the girls. In conclusion, we can summarize that both genders are dissenting; the adolescent prefers to be against the rules than to be part of them and to let them determine his wishes. Girls are more categorical in their answer "rarely", but the indicators are approximate to the answer "never". The young person, especially at this age, would hardly agree with any rules, especially if they are imposed as "external factor".

\section{Distribution by age}

The calculated criterion of consent of Pearson confirms the alternative hypothesis $-\mathrm{P}>0.05$ $\left(\chi^{2}=22.07\right)$. The latter is determined by the structural differences in the responses of students from different age groups.

Through the individual answers for compliance with the rules in the family we managed to determine the average age of the studied group (Table1). The calculated F-criterion of Tukey from the dispersion analysis confirms the null hypothesis, i.e. lack of statistically significant difference in the average age of the individual answers $-\mathrm{P}>0.05(\mathrm{~F}=0.83)$.

The greatest variability was registered in the group of the 14 year olds. The percentage of those responding "I respect the rules" "always" is the smallest among them; with over $20 \%$ larger is the registered answer "sometimes". In the following age groups have been registered minor differences in the answers "always" and "sometimes" obey the rules in the family. Considerable variability was registered for the answer "rarely observe the rules". The smallest percentage of "rare compliance" with rules at home is for 14-year-old students, followed by the 18-year-olds.

Every tenth student of 14 and 18 years of age responded that he "never" obey the rules of the family. This is due to the beginning of the identification process and its end, when the adolescent is trying to declare his independence and when at the end of this process he has already achieved it at any particular degree. At the age 15 and 16 those, who never follow the rules, are five percent, while the lowest percentage is for the 17-yearolds, which is $2.16 \%$.

\section{Distribution by school}

The profile of the school, the age and the gender composition of the students is supposed to influence the self-assessment for the rules in
TILOV B., et al.

the family. The calculated criterion of consent of Pearson confirms the alternative hypothesis at significance of $95 \% .0\left(\chi^{2}=34.59\right)$.

\section{Single factor analysis}

For the purposes of the study we collated the individual scales of the self-assessment questionnaire of Buss-Perry to measure the aggressiveness with the self-assessment question. The analysis results confirm the presence of significance. In the way of identification, the adolescent is faced with a series of externally fixed norms established by the family.

The relation between this statement and the scales for measurement of the levels of aggressiveness is in all scales. For scale "physical aggression" $\mathrm{P}<0.001(\mathrm{~F}=8.99)$, "verbal aggression" $\mathrm{P}<0.001 \quad(\mathrm{~F}=13.53)$, "anger" $\mathrm{P}<0.001$ ( $\mathrm{F}=9.82)$, "hostility $\mathrm{P}<0.05$ $(\mathrm{F}=13.19)$ and "general aggression" $\mathrm{P}<0.001$ $(\mathrm{F}=10.49)$. The interpretation of the values can be viewed both as an aggressive reaction on the enforcement of rules and as a sign that the adolescent needs firmness and clearly set boundaries, to which there is freedom of action. When the young person does not comply with the set rules and regulations, it would inevitably lead to escalating and extreme behavioral manifestations. Together with the constant anxiety and depressive predisposition the development of mental abnormalities and psychiatric diseases can be caused.

The opposing actions of the adolescent aim the reaching of validation of personal characteristics and qualities and selfvalidation. All this is triggered, when the adolescent is aware of the authority of the parent, steadfast, a person, who sets clear behavioral boundaries, which when violated, lead to a predetermined penalty. A number of authors explore the necessary and efficient image of the parent in this age - a parent, who has authority and supports the self-assertion of the young person, allowing him to show personal independence and a clear position, but consistent with the established "family law" and codes of conduct.

\section{CONCLUSIONS}

The family environment is the place, where the young person passes through the rapidly changing stages of his conscious life, stages associated with his physical, mental and emotional development. Undoubtedly, the authority of the parent or the guardian is the 
most significant determinant of the behavior of the adolescent.

Olweus (2004) pays special attention to the intrafamilial factors that provoke the formation of aggressive personality traits in the adolescent. According to him, most threatened by aggression are children, who come from:

- Incomplete families. A child brought up by a single parent is more likely to use emotional violence against other children.

- Families, in which the mother is suspicious or set negatively toward others, including the school of the child. She does not judge and does not correct her child's behavior and in conflict situations tends to justify aggression as a natural reaction.

- Powerful and authoritarian families. Upbringing in a dominant hyperprotection is characterized by unquestioning obedience to the will of the parents, which is why for the children of such families the school environment is the place, where they can reject the internal manifestations of fear and anger.

- Families, which are characterized by conflicting family relationships. In such families, the adults often quarrel and curse. Children learn this model and later apply it in their daily lives as a way to deal with situations. The frustrating and disturbing atmosphere in the family forces the child to protect himself by being aggressive. In such families mutual support and close relationships are virtually absent. Children, whose families practice violence, evaluated it differently from other children. When the adolescent has witnessed violent communication, for him the high tones and aggression are normal. Then he finds the physical and verbal violence between peers quite reasonable.

- Families with a genetic predisposition to violence. Children have a different genetic predisposition for tolerance. In those with a low tolerance level can be seen a high level of violent events (13).

In most cases the family environment stimulates or inhibits the development process of the young person. In the adolescence, the so-called puberty, the young person initially imagines his autonomy and "emancipation". In the middle of this process, he performs certain activities, with which is trying to prove and confirm his inviolable identity. Everything continues as intense period up to 18 years of age, defined in one degree or another by the external factors that have imposed certain rules and norms of the adolescent.
The opposition and oppositional behavior in this age is an active mean of expressing the desire for self-development and self-validation before the authority. The constant struggle between two generations of parents and adolescents is a necessary process that leads to preservation of the emotional balance and mental health. If this process is omitted, neglected or permanently suppressed, there is the danger of counter-productive processes in later life, when the personality of the young person is almost fully built and when the external resistance previously directed outwards transforms into internal. This internal resistance can lead to a number of changes and mental diseases, as the most common in this age are anxiety and depression, eating disorders (anorexia, bulimia), autoaggressive actions (suicide attempts), abuse of alcohol, drugs and stimulants.

The aggressive behavior during adolescence is an important psychological, pedagogical and medico-social problem that has no single solution, as the generally accepted preconditions of aggression have characteristics related to the personality and the age of each child.

In conclusion, we can summarize that the family is both a factor and a condition not only for the development and education of the child, but also for the overcoming of aggressive behavioral manifestations.

\section{REFERENES}

1. Moffitt, T.E., Adolescent-limited and lifecourse-persisting offending: A complementary pair of developmental theories. Developmental theories of crime and delinquency, pp.11-55, New Brunswick, NJ: Transaction Publishers., 1997

2. Moffitt, T.E., Caspi, A. \& Rutter, M., Strategy for investigating interactions between measured genes and measured environments. Archives of General Psychiatry, 62:473-481, 2005

3. Crick, N.R., Werner, N.E., Casas, J.F., O'Brien, K.M., Nelson, D.A., Grotpeter.J.K. \&Markson, K., Childhood aggression and gender: A new look at an old problem. In Gender anad Motivation: Volume 45 of the Nebraska Symposium on Motivation, Bernestein D., University of Nebraska Press, Lincoln, 75-141, 1999.

4. Raine, A., The Interaction of Biological and Social Measures in the Explanation of Antisocial and Violent Behavior, In D.M. Stoff \& E.J. Susman, Developmental 
Psychology of Aggression pp.13-42. Cambridge: Cambridge University Press., 2005

5. Moffitt, T.E., Adolescent-limited and lifecourse-persisting offending: A complementary pair of developmental theories. Developmental theories of crime and delinquency, pp.11-55, New Brunswick, NJ: Transaction Publishers., 1997

6. Patterson, G.R., The contribution of siblings to training for fighting: a microsocial analysis. In Development of Antisocial and Prosocial Behavior: Research, Theories and Issues, ed., pp. 23561. New York: Academic Press., 1986

7. Cummings, E.M., Iannotti., RJ. \& ZahnWaxler, C., Aggression between peers in early childhood: individual continuity and developmental change. Child Development, 60: 887-895, 1989.

8. Дончева, Ю., Преодоляване на формирани в семейството модели за агресивно поведение на детето, автореф. на дисертационен труд, С., 2011
9. Moffitt, T.E., Life-course-persistent and adolescence-limited antisocial behavior. A ten year research review and a research agenda. Causes of conduct disorder and juvenile delinquency, pp.49-75. NY: Guilford, 2003

10.Fontaine, R.G., Applying systems principles to models of social information processing and aggressive behavior in youth. Aggression and Violent Behavior, 11:64-76, 2006.

11.Moffitt, T.E., \& Lynam, D.R., The neuropsychology of conduct disorder and delinquency: Implications for understanding antisocial behavior. A developmental perspective, pp.233-262. New York: Springer, 1994

12.Crick, N.R., Werner, N.E., Casas, J.F., O’Brien, K.M., Nelson, D.A., Grotpeter.J.K. \&Markson, K., Childhood aggression and gender: A new look at an old problem. In Gender anad Motivation: Volume 45 of the Nebraska Symposium on Motivation, Bernestein D., University of Nebraska Press, Lincoln, 75-141, 1999.

13. Olweus, D., Billing at school. 2004. 